\title{
ПЕДАГОГІЧНІ УМОВИ ОРГАНІЗАЦІЇ ХУДОЖНЬО-КОНСТРУКТИВНОЇ ДІЯЛЬНОСТІ ДІТЕЙ ДОШКІЛЬНОГО ВІКУ В УМОВАХЗДО
}

general secondary education in the context of NUS ideas]. Youth \& market, Vol. 10(177), pp.126-130. [in Ukrainian].

6. Zakon Ukrainy "Pro osvitu" (2017). [Law of Ukraine "About education"]. No. 2145-VIII 28.09.2017 [in Ukrainian].

7. Kalenskyi, A. A., Luzan, P. H., Vanina, N. M., Pashchenko, T. M., Kravets, S. H. \& Piatnychuk, T. V. (2018). Standartyzatsiia profesiinoi osvity: teoriia i praktyka; monohrafiia [Standardization of professional education: theory and practice]. Monograph. Zhytomyr, 256 p. [in Ukrainian].

8. Kontseptsiia Novoi ukrainskoi shkoly (kolehiia MON vid 27.10.2016) [Concept of the New
Ukrainian School (MES Board dated October 27, 2016)]. Available at: https://mon.gov.ua/storage/app/ media/zagalna\%20serednya/nova-ukrainska-shkolacompressed.pdf [in Ukrainian].

9. Kontseptsiia profilnoho navchannia (2013). [The concept of specialized training]. Available at: http://www.uazakon.com/document/fpart86/ idx86618.htm [in Ukrainian].

10.Kushnir, V. M. (2016). Profilne navchannia v istorii rozvytku vitchyznianoi shkoly (druha polovyna XIX-XX st.) [Profile training in the history of domestic school development (second half of the XIX-XX centuries)]. Monograph. Uman, 418 p. [in Ukrainian].

Стаття надійшла до редакції 12.08.2021

УДК 377:37.011

DOI:

Галина Борин, кандидат педагогічних наук, доцент кафедри теорії та методики дошкільної і спеціальної освіти, Прикарпатського національного університету імені Василя Стефаника

\section{ПЕДАГОГІЧНІ УМОВИ ОРГАНІЗАЦІЇ ХУДОЖНЬО-КОНСТРУКТИВНОЇ ДІЯЛЬНОСТІ ДІТЕЙ ДОШКІЛЬНОГО ВІКУ В УМОВАХ ЗДО}

У статті охарактеризовано педагогічні умови організації художньо-конструктивної діяльності педагога з дітьми дошкільного віку в умовах закладу дошкільної освіти. Основну увагу зосереджено на виокремленні та обтрунтуванні педагогічних умов у руслі означеної проблеми. Наголочено, що вони трунтуються на загальнодидактичних та специфічних принципах, характеризуються певними вимогами до проведення художньо-конструктивної діяльності з вихованиями та спрямовані на задоволення особистісних потреб та інтересів дошкільників, їхню самореалізаџію у активній творчій діяльності. Чималу увагу зосереджено на тому, щь задля обтрунтування комплексу умов щзодо організації художньо-конструктивноі діяльності дітей дошкільного віку, варто враховувати низку факторів: суперечності, які існують в царині організації художньо-конструктивної діяльності з дітьми доикільного віку; принципи організації освітнього процесу з дошкільниками; характерні особливості художньо-конструктивної діяльності дітей дошкільного віку.

Ключові слова: художньо-конструктивна діяльність; діти дошкільного віку; дошкільний заклад освіти; вихователь; педагогічні умови; особистісно-діяльнісний підхід; творчий розвиток дітей.

Лim. 14.

Halyna Boryn, Ph.D. (Pedagogy), Associate Professor, of Theory and Methods of Preschool and Special Education Department Vasyl Stefanyk Precarpathian National University

\section{PEDAGOGICAL CONDITIONS OF ORGANIZING ARTISTIC AND CONSTRUCTIVE ACTIVITY OF PRESCHOOLAGED CHILDREN IN THE CONDITIONS OF PRESCHOOL INSTITUTIONS}

The article describes the pedagogical conditions for the organization of artistic and constructive activities of a teacher with preschool children in a preschool institution. The main attention is focused on the selection and justification of pedagogical conditions of this problem. It is emphasized that they are based on general didactic and specific principles, are characterized by certain requirements for artistic and constructive activities with students and are aimed at meeting the personal needs and interests of preschoolers, their self-realization in creative activity.

Considerable attention is paid to the fact that in order to substantiate the set of conditions for the organization of artistic and constructive activities of preschool children, it is necessary to take into account a number of factors: contradictions that exist in the organization of artistic and constructive activities with preschool children; principles of organizing the educational process with preschoolers; characteristic features of artistic and constructive activity of preschool children. 


\section{ПЕДАГОГІЧНІ УМОВИ ОРГАНІЗАЦІЇ ХУДОЖНЬО-КОНСТРУКТИВНОЇ ДІЯЛЬНОСТІ ДІТЕЙ ДОШКІЛЬНОГО ВІКУ В УМОВАХЗДО}

The study describes the pedagogical conditions for organizing artistic and constructive activities of preschool children: organization of artistic and constructive activities of preschoolers on the basis of personality-activity approach (it means that the activity is the main method of mental reflection of the surrounding reality in the mind); providing a creative atmosphere during the artistic and constructive activities (a friendly and attentive attitude of the teacher to the creative manifestations of the child); coordinated actions of pupils during the specified activity form the ability to coordinate their own actions with the actions of peers; taking into account the age and individual characteristics of preschoolers, creating a proper developmental environment (in determining the conditions for the proper provision of artistic and constructive activities of children there are provisions on the inheritance of mental properties and abilities); ensuring a proper material and sanitary-hygienic environment (it states the fact that artistic and constructive activities should be organized in a spacious bright room that meets the appropriate sanitary and hygienic standards).

Keywords: artistic and constructive activity; preschool children; preschool educational institution; educator; pedagogical conditions; personal-activity approach; creative development of children.

П остановка проблеми. Формування майбутньої успішної особистості в епоху трансформації української педагогічної науки набуває в наш час особливого значення. Зокрема, йдеться про розвиток творчих здібностей дітей, їх активності та самостійності. Художнс-естетичне виховання дітей дошкільників характеризується перманентним поступом, розпочинається шляхом сімейного виховання, а згодом - дошкільному закладі освіти.

Успішна організація художньо-конструктивної діяльності дітей дошкільного віку передбачає розробку із подальшою реалізацією педагогічних умов, що грунтуються на загальнодидактичних та специфічних принципах, характеризуються певними вимогами до проведення художньоконструктивної діяльності з вихованцями та спрямовані на задоволення особистісних потреб та інтересів дошкільників, їхню самореалізацію у активній творчій діяльності.

Аналіз останніх досліджень і публікацій. Проблеми художньо-естетичного виховання дітей досліджено упрацях С. Міхеєвої, В. Сухомлинського, К. Ушинського та ін. Філософсько-естетичні аспекти цієї проблематики висвітлено в наукових працях І. Гончарова, М. Киященко, В. Ядова тощо. Психологічні основи естетичного виховання вивчали Б. Ананьєв, Л. Божович, Л. Виготський, Б. Теплов та інші. На сучасному етапі питання художньо-естетичної діяльності дітей досліджують С. Василевський, Н. Волошина, В. Кардашов, В. Котляр, М. Масол, О. Сухорукова, Г. Фесенко тощо. Окремі аспекти організації занять 3 художньої праці в умовах закладу дошкільної освіти студіюють Н. Голота, Т. Єськова, С. Матвієнко та інші. Особливості формування художніх та конструктивних умінь майбутніх педагогів висвітлено у наукових студіях Г. Артемової, Н. Голоти, О. Попович, О. Сухорукової.

Мета статті- - дійснити аналіз педагогічних умов організації художньо-конструктивної діяльності дітей дошкільного віку в умовах закладу дошкільної освіти.
Виклад основного матеріалу. Задля обгрунтування комплексу умов щодо організації художньо-конструктивної діяльності дітей дошкільного віку, варто враховувати низку факторів: суперечності, які існують в царині організації художньо-конструктивної діяльності 3 дітьми дошкільного віку; принципи організації освітнього процесу з дошкільниками; характерні особливості художньо-конструктивної діяльності дітей дошкільного віку.

Результати аналізу наукової літератури засвідчують, що єдине визначення змісту поняття “педагогічні умови" відсутне. Згідно з Великим тлумачним словником, умова є сукупністю положень, покладених в основу чого-небудь [2]. Послугуємось тлумаченням В. Іванової, яка дефініцію “педагогічні умови” тлумачить як сукупність певних обставин, що забезпечують ефективність протікання освітнього процесу та сприяють виникненню і цілеспрямованому розвитку певного явища [5].

У освітньому процесі закладу дошкільної освіти дошкільник та вихователь перебувають у зонах розвитку особистісного досвіду. Під час художньо-конструктивної діяльності для дитини важливими стають потреби, мотиви творчої освітньої діяльності, особистісні цілі, а для вихователя - мета, зміст, форми, методи та прийоми, засоби навчання в означеному руслі. Слід також акцентувати на тому, що під час активної творчої діяльності в дітей розвиваються особистісні якості, які згодом можуть проявитися чи перенестись на іншу сферу діяльності.

Задля обгрунтування першої умови організація художньо-конструктивної діяльності за допомогою ігрових методів, що сприяе виникненню інтересу до добровільної участі дітей в означеному руслі - зауважимо, що однією із провідних видів діяльності дітей дошкільного віку $€$ гра. В іграх дітей виявляються здібності, індивідуальні особливості. Оскільки гра - це природний стан дитини, тому під час гри навчання й розвиток вихованця відбуваються для неї 


\section{ПЕДАГОГІЧНІ УМОВИ ОРГАНІЗАЦІЇ ХУДОЖНЬО-КОНСТРУКТИВНОЇ ДІЯЛЬНОСТІ ДІТЕЙ ДОШКІЛЬНОГО ВІКУ В УМОВАХЗДО}

непомітно. Саме ігрова діяльність найефективніше сприяє повноцінному розвитку особистості дошкільника. У грі діти відображають навколишню дійсність - взаємини людей, їхні дії та водночас вносять у гру й елементи власного світобачення та уяви, виявляючи свою самостійність. Проте кожен вихованець на власний розсуд “творить” гру, по-своєму відображає в ній свої уявлення про світ, виражаючи (демонструючи) власне ставлення до нього. Художньо-конструктивна діяльність дошкільників виникає із гри і водночас застосування педагогом ігрових методів допомагають дитині подолати побоювання, невпевненість 3 приводу того, що у них не вийде, оскільки вони створюють атмосферу відкритості, розкутості, забезпечують емоційно позитивне відношення до творчої діяльності, діти навчаються думати, експериментувати, самовиражатися. Результат художньо-конструктивної діяльності не може бути поганим чи хорошим, виріб (робота) кожної дитини - індивідуальний, неповторний. Це творчий процес, який викликає в дитини відчуття радості, оскільки спрямований на розвиток бажання творити. У результаті такої творчої діяльності дитина створює щось нове, не схоже на інше, розвиває свою уяву під час реалізації задуму.

Обгрунтування наступної умови - забезпечення належного матеріального та санітарно-гігієнічного середовища - полягає у тому, що художньоконструктивну діяльність слід організовувати у просторому світлому приміщенні, яке відповідає належним санітарно-гігієнічним нормам. Навчальне обладнання зони художньоконструктивної діяльності включає комплект меблів, матеріали, інструменти, необхідні для організації заняття.

3 метою обгрунтування наступної умови урахування вікових та індивідуальних особливостей дошкільників, створення належного розвивального середовища, зазначимо, що у визначенні умов належного забезпечення художньо-конструктивної діяльності дітей $\epsilon$ положення про успадкування психічних властивостей та здібностей (С. Рубінштейн, Л. Венгер). До художньо-конструктивних умінь та навичок важливими є сформовані навички координування дій ока й руки, що надає можливість виконувати конструкторські дії дії відповідної складності; володіння техніками роботи із певними матеріалами.

Художньо-конструктивна діяльність дітей розвиває логічне й абстрактне мислення, фантазію, спостережливість, увагу, уяву, формує впевненість у собі. Діти навчаються помічати знайомі обриси у невідомому, а згодом інтерпретують їх, відображаючи це у своїй творчості, здійснюючи пошук нешаблонних шляхів творчої діяльності. Використовуючи у роботі різноманітні матеріали (нитки, поролон, плівку, трубочки, пензлики для клею, сіль, папір. картон), діти розвивають асоціативне й логічне мислення. Також така робота сприяє розвитку окоміру, вчить поєднувати кольори, розвиває відчуття пропорції, симетрії, гармонії.

Характеристика наступної умови - забезпечення творчої атмосфери під час художньоконструктивної діяльності - полягає у доброзичливому й уважному ставленні педагога до творчих проявів дитини. Узгоджені дії вихованців на під час означеної діяльності формують уміння узгоджувати власні дії із діями однолітків. Відповідно до досліджень Є. Фльоріної, Н. Сакуліної, В. Котляра, Г. Підкурганної, успішності розв'язання художньо-конструктивних завдань сприяють як зовнішні, так і внутрішні умови організації освітнього процесу в ЗДО.

Зовнішні умови передбачають створення творчої атмосфери під час означеного виду діяльності дітей. Це знаходить відображення у доброзичливому й уважному становленні однолітків та дорослих до творчого прояву дитини; наявність належної матеріальної бази дає можливість дітям практично реалізувати творчі пошуки відповідно до задуму. До внутрішніх умов відносять сформованість системи психічних процесів, які сукупно забезпечують вихованцю можливість розв'язувати завдання, що виникають на кожному етапі художньо-конструктивної діяльності та становлять психологічну готовність до творчого процесу. Участь у колективних роботах, спільні емоції та переживання поєднують дітей, викликають радісний, піднесений настрій.

Обгрунтування наступної педагогічної умови - організація художньо-конструктивної діяльності дошкільників на основі особистісно-діяльнісного підходу - полягає у тому, що діяльність є головним методом психічного відображення навколишньої дійсності у свідомості особистості. На думку М. Кардашова, вивчення особливостей суспільної свідомості здійснюється через систему відносин у суспільстві (виробничих, соціальних, міжособистісних), а індивідуальних особливостей психіки особистості - через аналіз діяльності у певних суспільних умовах та життєвих ситуаціях [6]. За таких умов, за міркувань ученої, діяльність - це не реакція і не комплекс реакцій у їх взаємодії, а упорядкована система, що має власну побудову, внутрішні взаємозв'язки, характеризується гнучкістю, перманентним розвитком $[3,82]$. 


\section{ПЕДАГОГІЧНІ УМОВИ ОРГАНІЗАЦІЇ ХУДОЖНЬО-КОНСТРУКТИВНОӤ ДІЯЛЬНОСТІ ДІТЕЙ ДОШКІЛЬНОГО ВІКУ В УМОВАХЗДО}

Діяльність дитини дошкільного віку тісно пов'язана із діяльністю інших людей, у процесі якої вона набуває досвіду минулих поколінь, формує досвід власної діяльності, оволодіває формами, методами та способами їі реалізації, здійснює порівняльний аналіз [12]. Унаслідок цього посилюється мотивація вихованця, розширюється його кругозір, він набуває певних особистісних якостей. Особливою цінністю художньоконструктивної діяльності $\epsilon$ здобутки загальнолюдського досвіду, які згодом стають досвідом молодих поколінь [13]. Саме на основі набутого і засвоєного досвіду певної діяльності, лише у діяльності можна творити нові цінності.

Загальновідомо, що процес навчання асоціюється зазвичай з поняттями “навчальна діяльність” і “пізнавальна діяльність” та в педагогічній науці асоціюється із загальним терміном “уміння”. Проте завжди ці поняття оскільки вони охоплюють діяльність того, хто навчає (педагог), і того, хто навчається (дитина). Проаналізуємо детальніше дефініції “естетична діяльність" та “конструктивна діяльність” дітей дошкільного віку.

На думку Н. Копалової, естетична діяльність $\epsilon$ духовно-практичною, емоційно раціональною діяльністю дитини. Її змістом виступає побудова індивідуальної картини світу шляхом створення виразних художніх образів, а їі метою, за міркувань науковця є гармонізація відносин дитини зі світом, моделювання образу “Я”, як “концепції творця" $[7,3]$. У художньо-естетичній діяльності дітей дошкільного віку важливе місце має здатність сприймати художній твір, створювати власний виразний образ. Результат такої діяльності дитина відображає у своєму власному творчому продукті залежно від ії індивідуальних особливостей. Згідно iз дослідженнями I. Ликової, художньо-естетична діяльність є специфічною за своїм змістом та формами вираження, вона спрямована на естетичне опанування дитиною світу шляхом опанування мистецтва $[8,3]$.

Отже, художньо-естетична діяльність - це спосіб естетичного виховання дітей молодшого шкільного віку, система специфічних художньотворчих дій, спрямованих на сприйняття, пізнання і створення художнього образу в певному малюнку чи виробі для естетичного опанування світу.

За переконанням I. Реви, знання й дії, осмислені, усвідомлені і пережиті дитиною під час художньоестетичної діяльності, яка має в своїй основі передумови художньо-творчої діяльності, набувають дієвого характеру, стають основою дій та переконань вихованця, а згодом - основою поведінки і діяльності у суспільстві. Такі взаємопереходи лежать в основі перманентного розвитку особистості, оскільки внутрішня за формою діяльність виходить із зовнішньої практичної діяльності і зберігає двобічний зв’язок 3 нею. Набуті знання у процесі діяльності також впливають на дитину, змінюють їі мислення, формують процеси сприйняття [13]. Особистіснодіяльнісний підхід на основі якого покладено організацію художньо-конструктивної діяльності дітей дошкільного віку передбачає таку модель спілкування педагога з вихованцем, за якої особистісний компонент вибудовується 3 урахуванням минулого досвіду вихованця, його особистісних якостей.

В основу особистісно-діяльного підходу покладено психолого-педагогічні аспекти особистісно орієнтованого підходу. Їх грунтовно досліджено в працях I. Беха, О. Пєхоти, Г. Підкугарної, В. Рибалко, В. Сєрикова та ін. Зокрема, Г. Підкугарна переконує, що особистісно орієнтований підхід потребує організації освітнього процесу на засадах глибокої поваги до дитини, врахування особливостей ії індивідуального розвитку, передбачає формування цілісноӥ особистості, яка здатна усвідомити власну гідність і поважати інших людей [10]. Особистісний підхід передбачає послідовне ставленням дорослих до дитини як до особистості; передбачає допомогу їй у царині усвідомлення себе особистістю, допомогу у виявленні, розкритті власних можливостей, становленні ії самосвідомості, самоствердження, самореалізації [4; 10]. Відтак діяльнісний підхід спрямовано на організацію художньоконструктивної діяльності дошкільників у такий спосіб, щоб забезпечити їм активність у пізнанні, праці, діяльності, саморозвитку, самовдосконаленні.

Проаналізуємо мотиви, які спрямовують художньо-конструктивну діяльність дошкільників в умовах закладу дошкільної освіти. Їх ми поділяємо на декілька груп [12]: освітні мотиви - розкривають ставлення особистості до художньо-конструктивної діяльності (інтереси, потреби, які є основою активності і самостійності дошкільника); моральні мотиви - характеризують власне моральне ставлення особистості до навколишніх, а саме до ти, для яких власноруч виготовляють свої вироби чи виконують цікаві зображення; соціальні мотиви - спрямовують діяльність дошкільників на досягнення реальних художньо-конструктивних результатів, до певного місця в колективі учнів, до освітньої діяльності загалом.

Отже, художньо-конструктивна діяльність 


\section{ПЕДАГОГІЧНІ УМОВИ ОРГАНІЗАЦЇ ХУДОЖНЬО-КОНСТРУКТИВНОӤ ДІЯЛЬНОСТІ ДІТЕЙ ДОШКІЛЬНОГО ВІКУ В УМОВАХЗДО}

складається із окремих, пов'язаних між собою художньо-творчих дієвих аспектів, що спрямовані на усвідомлення дітьми цілей щодо досягнення відповідних творчих результатів.

Художньо-конструктивній діяльності дітей дошкільного віку притаманний активний, емоційно насичений, часто непередбачуваний зміст. Це вимагає застосування педагогом особистіснодіяльнісного підходу до налагодження взаємодії із дітьми дошкільного віку в означеному аспекті.

Належне керівництво означеним видом дитячої діяльності передбачає урахування вікових, індивідуальних особливостей дітей. Велике значення в організації художньо-конструктивної діяльності дітей відводимо особистості педагога, який, на думку О. Хорунжого [14], має належним чином підготуватися до неї: скласти тематичний річного (піврічний) плану роботи і конспектів до кожного заняття. План слід узгоджувати із розділами чинної програми, за якою працює ЗДО і який, зокрема, може включати декілька занять (які передбачають роботу з різними матеріалами, у різних техніках), присвячених одній темі. У плані передбачено бесіди, розповіді, досліди, матеріали, перелік основних практичних робіт, екскурсії, виставки, заключні заняття за темою.

На думку науковців $[9 ; 14]$ педагог, плануючи художньо-конструктивну діяльність дітей, зобов'язаний здійснити такі дії: ураховуючи психолого-фізіологічний, соціально-економічний аспекти діяльності, здійснює керівництво художньо-конструктивною діяльністю дітей на основі особистісно-діяльнісного підходу, педагогічно обгрунтовуючи вибір доцільних форм, засобів та методів роботи; сприяє формуванню художньо-естетичних інтересів дошкільників, забезпечуючи належні умови для повноцінного розвитку майбутньої творчої особистості; бере участь у розробці й реалізації освітніх програм, запроваджуючи сучасні технології виховання й розвитку дітей у художньо-естетичному напрямі; активно співпрацює із батьками дітей; забезпечує проведення занять із дотриманням правил організації освітньої та творчої діяльності у процесі користування різноманітними приладами й інструментами [9].

Відповідно до основних нормативних документів, освітній процес у закладі дошкільної освіти, має включати в себе такі види дитячої діяльності, які відповідають віку вихованців, в тих межах, в яких відбуваються важливі вікові новоутворення і надалі $є$ сприятливими для подальшого розвитку дитини дошкільного віку в усіх сферах життєдіяльності. Від педагогів, які організовують художньо-конструктивну діяльність
3 дошкільниками, залежить рівень їхнього художньо-естетичного виховання та розвитку.

Висновки і перспективи подальших досліджень. Задля належної організації художньо-конструктивної діяльності дітей дошкільного віку вихователь ЗДО повинен мати сформоване креативне педагогічне мислення, уміти бачити в кожному дошкільнику індивідуальність; повинен сам володіти моделлю продуктивного художньо-конструктивного пізнання і впроваджувати це у своїй діяльності. У центрі уваги вихователя має перебувати дитина як особистість у своїй унікальності, а кожне заняття має стати для вихованців відкриттям, на шляху пізнання естетики навколишнього світу. Отож, належним чином організована художньоконструктивна діяльність у закладі дошкільної освіти здатна забезпечити творчий вихованців. Саме на грунті гри, покладеної в основу художньоконструктивної діяльності дітей, зароджуються їхні творчі прояви майбутньої особистості.

Проведене нами дослідження не вичерпує порушеної проблеми. Напрямами іiї подальшого вивчення вбачаємо дослідження шляхів реалізації педагогічних умов художньо-конструктивної діяльності дітей в умовах закладу дошкільної освіти.

\section{ЛІТЕРАТУРА}

1. Борин Г.В. Діяльнісний підхід у професійній підготовці майбутніх педагогів до творчої художньо-конструктивної діяльності з дітьми дошкільного віку. Науковий журнал: Освітній простір Украӥни. Івано-Франківськ, 2019. Випуск 14. С. 57-63.

2. Великий тлумачний словник сучасної української мови (з дод. і допов.) / уклад і голов ред. В.П. Бусел. Київ, 2005. 1728 с.

3. Долинна О., Низковська О. Гурткова робота. Дошкільне виховання. 2004. №11. С. 8-9.

4. Долинна О., Низковська О. Про організовану і самостійну діяльність дітей у дошкільному навчальному закладі. Дошкільне виховання. 2011. №10. С. 7-10.

5. Здібності, творчість, обдарованість: теорія, методика, результати досліджень/заред. В. О. Моляко, О. Л. Музики. Житомир, 2006. 320 с.

6. Кардашов М. В. Теорія і методика викладання образотворчого мистецтва: Навчальний посібник для студентів вищих навчальних закладів. Київ, 2007. 296 с.

7. Копалова Н. Гурткова робота $з$ аплікації та оригамі. Тернопіль, 2007. 80c.

8. Ликова I.О. Програма художнього виховання, навчання й розвитку дітей 2-6 років “Кольорові 


\section{ПЕДАГОГІЧНІ УМОВИ ОРГАНІЗАЦЇ̈ ХУДОЖНЬО-КОНСТРУКТИВНОЇ ДІЯЛЬНОСТІ ДІТЕЙ ДОШКІЛЬНОГО ВІКУ В УМОВАХ ЗДО}

долоньки”. Харків: Веста: Видавництво “Ранок”, 2007. $128 \mathrm{c}$.

9. Москаленко М. Організація роботи гуртків, секцій, клубів, творчих об'єднань узагальноосвітніх навчальних закладах. URL: www.ippo.org.ua/files.

10.Навчально-методичні матеріали до Модельної навчальної програми для першого класу / Укладачі: О. Волощенко, О. Козак. 2018 р. URL: http://nus.org.ua/wp-content/uploads/2018/01/ Tyzhden_18_YA-Mandrivnyk.pdf

11. Національна доктрина розвитку освіти України у ХХІ столітті: Проект. Київ, 2001. 24 с.

12.Пустовійт Г. Позашкільна освіта та виховання крізь призму сьогодення. Рідна школа. 2010. №3. С. 28-31.

13.Рід Г. Проект концепції єдиної системи естетичного виховання у загальноосвітніх школах України. Мистецтвво та освіта. 1998. № 1. С. 2-7.

14.Хорунжий О. Практикум в навчальних майстернях 3 методикою трудового навчання. Тернопіль: Астон, 2001. 220 с.

\section{REFERENCES}

1. Boryn H.V. (2019). Diialnisnyi pidkhid u profesiinii pidhotovtsi maibutnikh pedahohiv do tvorchoi khudozhno-konstruktyvnoi diialnosti z ditmy doshkilnoho viku [Activity approach in professional training of future teachers to creative artistic and constructive activity with preschool children]. Scientific journal: Educational space of Ukraine. Ivano-Frankivsk. Vol. 14, pp.57-63. [in Ukrainian].

2. Busel, V. (Ed.). (2005). Velykyi tlumachnyi slovnyk suchasnoi ukrainskoi movy (z dod. i dopov.) [Large explanatory dictionary of the modern Ukrainian language (with revisions and additions)]. 1728 p. [in Ukrainian].

3. Dolynna, O., \& Nyzkovska, O. (2004). Hurtkova robota [Group work]. Preschool education. No.11, pp.8-9. [in Ukrainian].

4. Dolynna O., \& Nyzkovska O. (2011). Pro orhanizovanu i samostiinu diialnist ditei u doshkilnomu navchalnomu zakladi [About organized and independent activity of children in preschool educational institution]. Preschool education. No.10, pp.7-10.[in Ukrainian].

5. Moliako, V., \& Muzyka, O. (2006). Zdibnosti, tvorchist, obdarovanist: teoriia, metodyka, rezultaty doslidzhen [Abilities, creativity, talent: theory, methods, research results]. Zhytomyr, 320 p. [in Ukrainian].

6. Kardashov, M. V. (2007). Teoriia i metodyka vykladannia obrazotvorchoho mystetstva: Navchalnyi posibnyk dlia studentiv vyshchykh navchalnykh zakladiv [Theory and methods of teaching fine arts]. A textbook for students of higher educational institutions. Kyiv, 296 p. [in Ukrainian].

7. Kopalova, N. (2007). Hurtkova robota z aplikatsii ta oryhami [Group work on applications and origami]. Ternopil, 80 p. [in Ukrainian].

8. Lykova, I.O. (2007). Prohrama khudozhnoho vykhovannia, navchannia y rozvytku ditei 2-6- rokiv "Kolorovi dolonky" [The program of art education, training and development of children 2-6 years "Colourful palms"]. Kharkiv, 128 p. [in Ukrainian].

9. Moskalenko, M. Orhanizatsiia roboty hurtkiv, sektsii, klubiv, tvorchykh obiednan u zahalnoosvitnikh navchalnykh zakladakh [Organization of work of circles, sections, clubs, creative associations in general educational institutions]. Available at: www.ippo.org.ua/files. [in Ukrainian].

10. Navchalno-metodychni materialy do Modelnoi navchalnoi prohramy dlia pershoho klasu [Teaching materials for the Model curriculum for the first grade]. (Ed.). O. Voloshchenko, O. Kozak. 2018. Available at: http://nus.org.ua/wp-content/uploads/2018/01/ Tyzhden_18_YA-Mandrivnyk.pdf [in Ukrainian].

11. Natsionalna doktryna rozvytku osvity Ukrainy u XXI stolitti: proekt (2001). [National Doctrine of Education Development of Ukraine in the XXI Century: Project]. Kyiv, 24 p. [in Ukrainian].

12. Pustoviit, H. (2010). Pozashkilna osvita ta vykhovannia kriz pryzmu sohodennia [Extracurricular education and upbringing through the prism of today]. Native school. No.3, pp.28-31. [in Ukrainian].

13. Rid, H. (2008). Proekt kontseptsii yedynoi systemy estetychnoho vykhovannia u zahalnoosvitnikh shkolakh Ukrainy [Draft concept of a unified system of aesthetic education in secondary schools of Ukraine]. Art and education. No.1, pp.2-7. [in Ukrainian].

14. Khorunzhyi, O. (2001). Praktykum v navchalnykh maisterniakh $\mathrm{z}$ metodykoiu trudovoho navchannia [Workshop in training workshops with methods of labor training]. Ternopil, 220 p. [in Ukrainian].

Стаття надійшла до редакції 19.08.2021

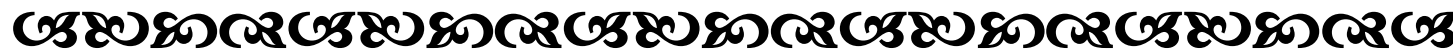

"Dопомагайте тим, хто хоче працювати, але поқи не може вибрати собі заняття по душі".

$$
\text { Марія Монтессорі, італійський педагоz, лікар, білособб }
$$

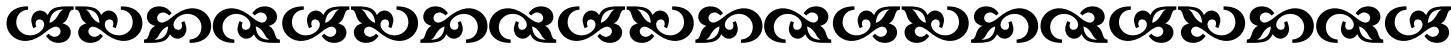

